\title{
Edwin Southern, DNA blotting, and microarray technology: A case study of the shifting role of patents in academic molecular biology
}

\author{
DAIDREE TOFANO, ILSE R. WIECHERS \& ROBERT COOK-DEEGAN ${ }^{1}$
}

\begin{abstract}
Edwin Southern developed a blotting technique for DNA in 1973, thereby creating a staple of molecular biology laboratory procedures still used after several decades. It became a seminal technology for studying the structure of DNA. The story of the creation and dissemination of this technology, which was not patented and was freely distributed throughout the scientific community, stands as a case study in open science. The Southern blot was developed at a time when attitudes about commercial intrusion into health research were beginning to change and the practical value of molecular genetics was becoming apparent to industry. Interest from industry in fundamental molecular biological techniques meant that scientists began to think about commercial uses of their work even in otherwise "basic" research. The unpatented Southern blot is contrasted with later patented technologies, particularly microarray methods, which were created in the same environment by many of the same people, but which followed significant changes to UK policies encouraging commercialization of academic research and a norm shift friendlier to such commercialization within academic molecular biology. Professor Southern's personal experience illuminates how the technologies evolved, and his views provide insight into how scientists' attitudes about commercialization have changed.
\end{abstract}

\section{An Environment for Innovation}

Edwin Southern studied chemistry at University of Manchester and then went on to study nucleic acids, receiving his Ph.D. in biochemistry from the University of Glasgow in 1962. After working for four years at the Antarctic Research Centre Low Temperature Research Station in Cambridge, he joined the MRC Mammalian Genome Unit in Edinburgh in 1967. A pioneer institution in the field that would eventually be called genomics, ${ }^{2}$ the Mammalian Genome Unit's staff consisted of several people who would later become leaders in the burgeoning field. Professor Sir Kenneth Murray was among the future genomics heavyweights whom Southern identifies as mentors. Murray co-discovered the Hepatitis B antigen and later cofounded the biotechnology company Biogen, one of the early biotechnology start-up firms, and the first to span the Atlantic.

A collegial environment within the Mammalian Genome Unit promoted innovation while allowing for a great deal of open sharing of scientific findings. According to Southern, competition rarely led to knowledge-hoarding, and information flowed relatively freely both within and between laboratories. ${ }^{3}$ To illustrate this open scientific culture, Southern cites the participation of his fellow scientists in a "restriction enzyme club," active during his time at MRC:

'People were very keen to share. Just to give you one example, when restriction enzymes first came out... Ken Murray in Edinburgh set up a club to make restriction enzymes. To join the club, you had to 
make one, and you had to share the one you made with everyone else. It was very much a culture of sharing. And, I think as far as technology is concerned, whenever anybody had a technique in their lab, they were very keen to teach other people to apply it in their own work.' 4

Competition among researchers certainly existed in the Unit; unfettered informationsharing is a utopian ideal rarely realized in practice. A general culture of sharing nonetheless prevailed, and contributed to Southern's success in innovation. Peter Walker's lab, in particular, proved to be an excellent place for Southern to exploit his knack for inventiveness. Peter Walker, head of the Unit, was himself an innovator and promoted instrument development through a "creation workshop" in his lab. ${ }^{5}$ If a researcher working in Walker's lab did not have the proper piece of equipment to complete an experiment, the researcher could go into the workshop and build the needed device. Walker's lab thus married scientific inquiry to practical design and prototyping of instruments, and was poised for the development of innovative technology.

Two crucial factors influenced Southern's innovation process: "necessity...the mother of invention"6 and "laziness, the father."7 Driving Southern's development of the new blotting technology was the need to isolate the 5S ribosomal RNA (rRNA) genes, which he needed to study the transcription of ribosomal RNA from DNA. The usual method for purifying genes at that time, density gradient centrifugation, turned out to be inadequate for the task. Southern instead isolated these genes by cutting the DNA with restriction endonucleases and separating the fragments by size through gel electrophoresis. Having separated genes in a gel, Southern was then confronted with the dilemma of extracting these genes back out of the gel. As Southern stated, "the prospect of cutting lots of gels into hundreds of slices, eluting the DNA from each of them and binding this to a filter that would then be hybridized and counted drove me to think that there had to be a better way of doing it." way," Southern invented his new blotting method.

\section{Southern's Invention}

The Southern blot is an ingenious synthesis of prior technologies and biological findings. A few years before the Southern blot was developed, Tom Kelly and Hamilton Smith, both at Johns Hopkins University, had shown that restriction endonucleases cut at specific sequence sites along DNA. ${ }^{9}$ Kenneth and Noreen Murray introduced Southern to these restriction endonucleases. In 1971, Kathleen Danna and Daniel Nathans, also of Johns Hopkins, showed how gel electrophoresis could separate DNA fragments. ${ }^{10}$ Southern credits Frederick Sanger's work with bringing to his attention "the notion of transferring DNA fragments from one medium to another." via electrophoresis and transferred the molecules to DEAE paper by "blotting through." 12 Southern integrated these three innovations-restriction endonucleases, gel electrophoresis, and blotting-through methods-to create the Southern blot.

The Southern blot process works as follows: DNA to be analyzed is digested into small pieces by restriction enzymes. ${ }^{13}$ The millions of resulting DNA fragments then undergo gel electrophoresis, which separates the fragments according to size. Once 
the DNA is separated in the gel, the gel is placed on filter paper, where capillary action transfers the alkali-denatured DNA fragments from the gel to a nitrocellulose filter (as originally used by Southern) or nylon membrane (adopted later) - the "blotting" step. Once bound and immobilized on a surface medium rather than embedded in a gel, the DNA can easily be incubated under hybridization conditions with labeled DNA probes. These probes can be detected by radioactivity, fluorescence, or other methods, allowing for the visualization of the DNA fragments that are bound to the probes.

As soon as the Southern blot idea was explained, its utility was both obvious and extensive. Nearly every molecular biology laboratory engaged in DNA studies had to separate DNA fragments, and the Southern blot greatly increased the speed and simplicity of this process. Southern's blotting method was used to clone genes and study gene expression, among many other DNA structural analysis applications.

\section{Dissemination of the New Technology}

Southern's attempts to publish his findings were delayed. Though he invented the Southern blot sometime in 1973, his publication was not in print until $1975 .{ }^{14} \mathrm{His}$ original submission to the Journal of Molecular Biology was rejected on the grounds that it was a methods paper, which the journal would only publish if it incorporated original and interesting results. ${ }^{15}$ To prove that he had developed a novel technique worthy of publication, Southern needed to conduct further experiments.

Figure 1. Example of a pre-publication sketch for the Southern blot. (Courtesy of Edwin Southern.)

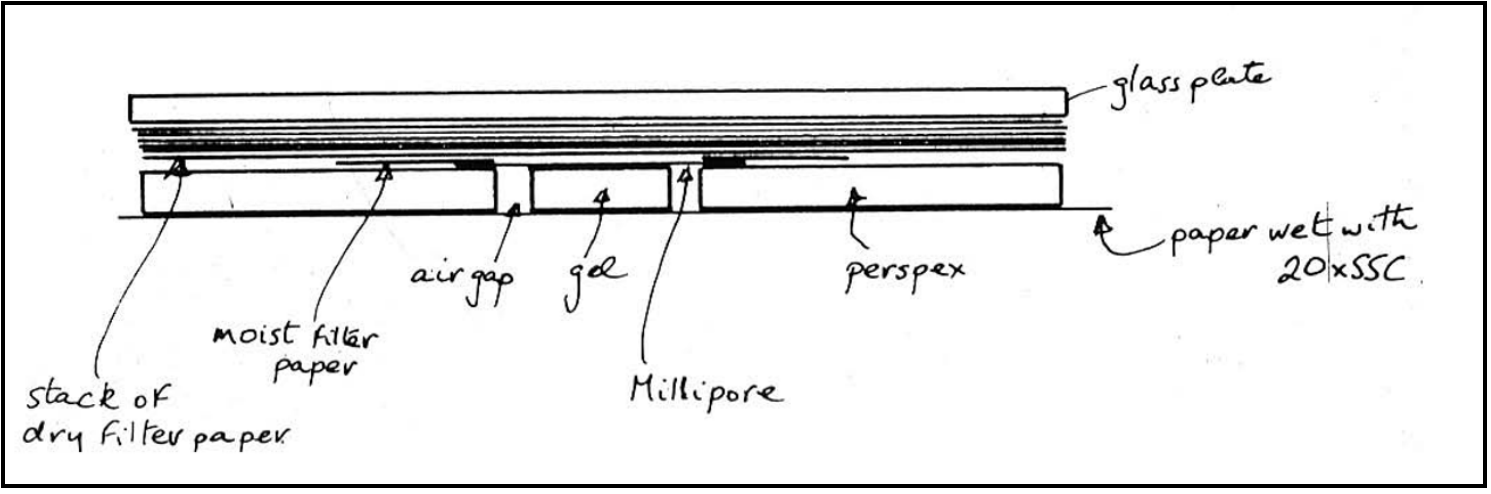

Southern did not wait for his work to be published to spread his findings. While he was running experiments and gathering more data for a publication, he engaged in a very liberal pre-publication sharing strategy. Dissemination of the Southern blot started at the hands of Michael Matthews, a scientist from Cold Spring Harbor Laboratory, who saw Southern's work during a visit to the Mammalian Genome Unit and wanted to take the technique back to the United States to use in his own work on viruses. Southern literally drew a schematic on a scrap of paper and gave it to Matthews who, "clutching this drawing," carried Southern's idea back with him to Cold Spring Harbor (see Figure 1). ${ }^{16}$ Back in the United States, Matthews and his colleague Mike Botchan implemented and improved upon the technique. Word about 
this hot new blotting method began to quickly spread through the research community.

Realizing the demand for Southern's blotting method, the people at Cold Spring Harbor asked Southern if they could further disseminate the information. Southern agreed, requesting only that he receive acknowledgement for the origination of the process. Southern considers his prepublication strategy to be the reason his name became entwined with the technique, stating "I believe that, if it had been published in the normal way, it would not have had such a firm attachment." ${ }^{, 17}$ When questioned about the prepublication sharing of information, he said "I've obviously no regrets about doing that." 18

Southern's open sharing of his method, coupled to a request for attribution, closely parallels the "for attribution" option of the Creative Commons licensing scheme. Creative Commons was founded in 2001 in part to bring a similar openness to written and creative works. ${ }^{19}$ The Creative Commons assists creators in choosing how their expressions will be licensed. The "for attribution" option is popular with academics and artists, as it enables others to use the material at no cost, but ensures credit for expression or innovation. The "Southern blot" is an extremely successful instance of this mechanism.

\section{Shifting Ideals}

In 1973, Professor Southern invented the Southern blot and used an open, informal method of prepublication to disseminate knowledge of his technology, subject only to acknowledgement of its creator. In 1985, he moved from MRC to assume the Whitley Professorship of Biochemistry at Oxford University, and, the next year, submitted his first patent application. He has since received more than 90 patents in various jurisdictions worldwide. ${ }^{20}$ An interesting contrast to the Southern blot is the microarray technologies that Southern patented. Southern remained within an open, academic research environment throughout his career, and stayed committed to sharing scientific information and methods, but he now files patents for his inventions where he did not even consider patenting an option in the 1970s. Professor Southern's story shows one man's evolving view of the appropriate relationship among open science, patenting, and commercial biotechnology. Four personal and environmental changes have accompanied this evolution:

- Policy affecting intellectual property (IP)

- Attitudes about science norms

- Southern's role in science

- The nature of the technologies

\section{Policy affecting IP}

UK policies regarding assignment of intellectual property rights for inventions using public funds changed in 1985. These policies reflected shifting perceptions of academic-industrial relations, which reflected a consensus among stakeholdersuniversities, industry, and government - that academic research could enhance social benefit through commercialization. This reversed a post-war consensus that promoted nationalization of many previously privately-held companies, including transportation 
systems and utilities. ${ }^{21}$ In 1948, Parliament passed the Development of Inventions Act, which set up the National Research Development Corporation (NRDC), the result of a long debate on how to prevent science and technology decline in Britain. Her Majesty's Treasury officially granted the right of first refusal for inventions arising from government funding to NRDC in a Treasury Circular in 1950, TC5/50. ${ }^{22}$ As a result, intellectual property rights to inventions created using public funds went to the NRDC (and later, the British Technology Group (BTG)). ${ }^{23}$

The management of intellectual property from publicly-funded research changed in the 1980s under the Thatcher government. The Thatcher years were "marked by the intensification of fears that British science was in serious trouble." ${ }^{24}$ Thatcher employed the same logic to remedy the ebb in British science that she often did in economics: roll back the state, and let market forces and enterprise dictate. On 14 May 1985, the Thatcher government officially rescinded TC5/50 and abolished the BTG right of first refusal on patents. ${ }^{25}$ As a result, consumers of public research funds, in particular universities, were allowed to own and commercialize the intellectual property resulting from in-house inventions. The UK policy change, encouraging universities to patent inventions arising in publicly-funded research, paralleled the shift in US policy, specifically the Bayh-Dole statute of $1980{ }^{26}$ The Bayh-Dole statute, in turn, reflected a growing U.S. consensus that public benefit would be best achieved by creating incentives to patent and license inventions arising from public science to private firms for subsequent development into commercially valuable products and services. ${ }^{27}$ The change in policy happened just as commercial biotechnology was taking shape, as cell fusion and recombinant DNA technologies began to find use in drug discovery, diagnostics, agriculture, and other applications.

Before being granted the right to own patents, however, a university in the UK first had to prove to the U.K. Research Councils that it possessed the resources and capabilities to manage its own intellectual property. The public Research Councils took different approaches to assigning intellectual property rights to universities. The situation was clarified after the 1999 Baker Report. In this report, John Baker submitted recommendations to the Minister for Science and the Financial Secretary to the Treasury for "increasing the rate at which their [Public Sector Research Establishments] research is successfully commercialized." ${ }^{28}$ The government responded by requiring Research Councils to specify the disposition of intellectual property at universities and other public research institutions. ${ }^{29}$ This reduced, although it did not entirely eliminate, variability among the Councils.

With the Thatcher directive to patent and license inventions arising from governmentfunded research, universities jumped at the opportunity to own intellectual property, including Oxford, where Southern now worked. In 1988, as a direct result of the Thatcher Administration changes, Oxford University formed Isis Innovation, a wholly-owned subsidiary designed to help the university exploit intellectual property. ${ }^{30}$ Intellectual property created at Oxford became generally assigned to Isis, which transferred the technology to industry through licensing agreements. Professor Southern was on the original board that helped to form Isis, thus intricately involving him in the academic research commercialization process at Oxford. 
Southern's choices concerning intellectual property and dissemination of his technologies shifted in concert with the UK policy changes. The Southern blot was invented in 1973 at a public sector research establishment (MRC Mammalian Genome Unit) in Edinburgh during a time when the UK endorsed government ownership of publicly funded research products. If patented, rights to the invention would have resided with government, through the NRDC; instead it was not patented at all. The Southern blot was created before the 1985 Thatcher changes and was not patented; the microarray was created after the 1985 policy changes and was patented. The policy change is far from the only difference, but the change of policy was one necessary condition for Southern, and Oxford, to patent microarray technologies.

Indeed, a lack of university interest in IP pursuits is reflected in the story of the Southern blot. Southern does not recall being approached by his employers to patent the Southern blot, nor does he recall even thinking about the possibility of patenting his invention. Southern claims that "nobody was bothered about patents at that time," but feels that if he invented the Southern blot today, he would undoubtedly have been approached about patenting the technique. ${ }^{31}$ Instead, Southern freely distributed information about how to reproduce the technique on the back of napkins and envelopes and through word of mouth. After a couple of years of this pre-publication dissemination strategy, Southern's paper was published in the Journal of Molecular Biology. The way MRC handled the Southern blot suggests that either MRC did not actively pursue IP or that Southern was not aware that MRC was concerned about IP. In a professional environment not openly concerned with IP production, it is not surprising that Southern did not consider patenting an option, or that he was never approached about patenting his invention.

By the time Southern filed his first patent application in 1985 and began work on microarray technologies in 1987, the IP policy landscape in the UK had shifted dramatically. Thatcher rescinded TC $5 / 50$ in 1985 , allowing universities to own and exploit IP, and various other UK laws and regulations had come into effect to promote privatization and commercialization. As a direct result of these changes, Oxford University established Isis Innovation, a TTO created to exploit IP resulting from inventions created at Oxford. Oxford now had a greater financial incentive to patent, and with a unit dedicated to getting and managing patents, the capacity to encourage employees to report patentable inventions.

Southern was not a passive recipient of the effects of policy changes at Oxford, but was actively involved in the transformation. As a founding member of the Isis board, he helped to create and shape Isis Innovation. Likewise, Southern was not approached about patenting the microarray at Oxford. Rather, he approached Isis about patenting his technology. Since he was on the board of Isis, he felt that "it seemed a good idea to give it [Isis] something to work on." ${ }^{32}$ However straightforward the motivation for patenting the microarray, implicit in Southern's actions was a greater knowledge and active acceptance of patenting scientific innovation. In the intervening years, Southern had learned about the possibilities and processes for pursuing IP. In submitting his work actively and voluntarily for patenting, Southern showed his acceptance of an emerging university IP exploitation system. 


\section{Attitude about science norms}

Changing policy and financial incentive may have both directly and indirectly influenced Southern's decisions regarding the methods used to share his technologies, but Southern's personal views on science norms - and the role that patenting plays in those norms-also altered. During an interview with Southern conducted last July, Southern was asked if he knew "anybody in the 1970s who patented a biotechnology," and if so, how he felt about this person. Southern answered:

'A friend of mine, Ken Murray, patented a vaccine for Hepatitis B. And we thought, I mean, it was the feeling, actually, that he was a bit of a sell-out. But he's redeemed himself since then, because he's made a lot of money out of it which he used in charitable ways. So nobody says now that it was something he shouldn't have done. If he had just made himself rich and spent it on women and sports cars, I think we'd probably have taken a different view. ${ }^{33}$

Murray was working in a laboratory at MRC at the time of Southern's invention. In 1978, three years after the first Southern Blot article was published, Murray and Heinz Schaller, of the University of Heidelberg, filed applications for what became European patents EP0182442 and EP0013828, based on their work producing Hepatitis B virus antigens. ${ }^{34}$ Murray and Schaller assigned their Hepatitis B patent rights to Biogen, a biotechnology startup company that Murray had helped co-found that same year with future Nobel Laureates Walter Gilbert, Philip Sharp, and other molecular biology luminaries. Murray's patent on the Hepatitis B antigen was one of the first patents of its kind in the UK.

Southern's characterization of the Murray Hepatitis patent is interesting. He was specifically asked about how he felt about a scientist who patented a biotechnology, but Southern answered in the plural we. Southern framed his response as the collective perception of a larger scientific community when queried about his own opinions about biotech patenting, and specifically about his friend Kenneth Murray. Southern's statement also shows how Kenneth Murray was retroactively redeemed by how he used the profits gained from the IP in "charitable ways." Importantly, when recalling how he felt in the 1970s about patenting, Southern tells a tale of negative judgment. Implicit in Southern's statement is that his concept of scientific norms in the 1970s did not include patenting.

Contrast how Southern describes himself in the 1970s with how he speaks today about biotechnology IP. Southern now thinks explicitly and at length about IP strategies and about when to patent and when to publish and when to do both. He is an adept businessman as well as scientist, and he expresses mastery of the technical language in both arenas. Southern did express judgment about biotech IP, but did not use language about morality to discuss his qualms. For instance, he stated that he wished "weak, defensive patents" were not so pervasive as they are really "a killer," but he did not lament over the immorality of biotech patenting per se. ${ }^{35}$ IP has incorporated itself into Southern's conception of science norms. Open sharing is no longer necessarily free dissemination of an unpatented technology, but now also includes liberal and feasible licensing procedures designed to make a technology as widely 
available as possible. IP is as routine and expected in scientific research as, well, the Southern blot.

Edwin Southern in the 1970s felt very differently about the relationship between science norms and IP than he does today. What changed his opinions? When did his views about IP change? Here, Southern recounts his experience (and that of the science community at large) in the 1980s as shifting away from science norm ideals that exclude IP towards a forced acceptance of IP by research institutions:

\begin{abstract}
'I think gradually I became under pressure. We all had to, we were under contract actually, to tell our funding agencies of any inventions which were patentable, anything in our work that could be commercialized. And at first, we were very resistant to that attitude. We thought that this would do the things you've been hinting at, you know, inhibit the spread of ideas and materials and so on. And so there was a resistance to that initially. When did that change? I think by mid-80's it was beginning to change. People were beginning to accept the idea that we had to do it, and that eventually became a sort of matter of course. I don't know anybody now who would put up a really strong resistance to that idea. They may not like it, but they would conform.' 36
\end{abstract}

From this statement, and from Southern's decisions about intellectual property, it is clear that a shift in Southern's thinking about the role of patents in academic research changed between 1973 and 1985.

\title{
Southern's role in science
}

"We are pleased that the English courts have agreed to decide this issue as a preliminary issue, and believe that they will declare invalid Affymetrix's attempts to secure a license by means other than negotiation with OGT."37 In this Oxford Gene Technology (OGT) press release, Professor Southern sounds more like an IP lawyer or a business shark than he sounds like a scientist. As Southern entered into the world of science and IP interactions and became invested in these interactions both personally and financially via OGT, he acquired several roles. In the 1970s, Southern was primarily a scientist, and also a colleague, friend, lab group manager, etc. Today, Southern is all these things, but he must also be an amateur lawyer and businessman. One of the key changing components in Southern's story is his personal migration towards becoming an industry-savvy scientist, as opposed to a scientist who practices only pure science.

\section{Nature of technologies}

In addition to Southern changing views on patenting since the 1970s, the technologies in question - the Southern blot and the microarray-are very different in terms of both complexity and marketing potential. One reason the Southern blot is widely used as a molecular biology procedure is that it is easily reproduced with materials laboratories have at hand. All a Southern blot requires is a "paper towel and a baking tray and some salt solution." 38 But the Southern blot's simplicity also renders it difficult to package as a profit-making product or service. A prepackaged and more 
costly Southern blot kit is a hard sell if potential buyers can build the product themselves much cheaper and without great effort.

Microarray technologies, in contrast, require extensive instrumentation, and their use entails detection methods and interpretation software. Meanwhile, integrating the components entails substantial engineering, and final products and services involve substantial investments and the kind of engineering work that universities are unlikely to undertake beyond the prototype stage. Moreover, economies of scale in production are apparent, as is the need for quality control, making dedicated manufacture and sale by private firms an efficient mechanism to produce them. Unlike the Southern blot which requires only commonly used materials, the microarray consists of small, clean chips spotted with thousands of oligonucleotide strands that must be synthesized. For a laboratory to produce its own microarray chips, the lab must have expensive equipment and expert staff, and must use many microarray chips for the equipment expenditure to be cost effective. Small laboratory outfits may not have the resources to produce their own microarray chips, and if it were not for microarray chip production companies, might be excluded from research that utilizes microarrays. Southern believes:
'In the case of microarrays, to do it properly you have to commercialize it. I think the "home-brew" business of microarrays sort of works alright, but it's clear by now, I think, that the commercial flavors of microarrays are superior to the home-brew flavors. You might find people that would argue with that, but I think... I'm sure that's really true.' ${ }^{39}$

As microarray chips are difficult and costly to produce, there is more of a potential for a microarray market than there is for a Southern blot market. Furthermore, a patent on microarray technologies is likely to be more profitable than a patent on the Southern blot would have been. One factor influencing the degree of profitability for these patents is the ability to enforce the patents via legal action. Because Southern blots are easily replicated, bringing litigation against infringing uses of Southern blot patents would be difficult. Microarray patents have the potential for being easier to enforce, since the skill and money required to produce microarrays would eliminate the possibility of every small lab outfit producing their own. Moreover, patents can be licensed to manufacturers, rather than enforced against individual researchers using a simple laboratory method. Legal action concerning microarrays can be directed at larger lab groups and companies, making litigation procedures practical and potentially effective.

Deciding what to do with a technology — whether to patent or publish, or bothrequires sophistication in balancing science and business. It is important to be able to judge the cost and benefits of patenting, versus more liberal dissemination methods through publication or free, open sharing. Although one might apply for many patents, very few of those patents will "actually [pay] off." Southern reasons:

'It's a startling statistic, the costs of filing a patent are quite high as you undoubtedly know. You've got to pay your lawyers, in Europe you've got to pay - to maintain the thing - you've got to pay translation costs, so the total cost of taking a patent through to point where it is really useful is about $£ 20,000$ to $£ 50,000$. You can almost 
double that for dollars... That's serious money. To earn that sort of money, let's suppose it's something that could bring in a 10 percent royalty... To justify a 100,000 dollar investment in the filing of the patent, it's got to be a million dollar invention. Just to break even. To make anybody any money, it's got to be a 10 million dollar invention. There aren't many of those around. ${ }^{, 40}$

The contrast between the profitability of the Southern blot and the microarray exemplifies one potential cause of the rise in biotechnology patenting in recent years. As Walsh and Cohen note, "the revolution in molecular biology, combinatorial chemistry, bioinformatics and related fields... has spawned discoveries of enormous commercial value since the 1970s. ${ }^{, 1}$ Higher commercial value, increasingly complex technology, and need for greater development investment have all contributed to more patenting of molecular biological inventions, in addition to changes in scientific norms.

\section{Conclusions}

Professor Sir Edwin Southern's story shows the fruitful career of one man in a rapidly changing social and scientific environment. Southern is the father of several successful inventions, including the Southern blot and some seminal patents in microarray technologies. Southern invented the Southern blot in 1973 and used an informal method of prepublication to disseminate knowledge of his technology until it was published in the Journal of Molecular Biology in 1975. A decade after the Southern blot, in 1985, Southern left the MRC Mammalian Genome Unit in Edinburgh to become the head of the biochemistry department at Oxford. That same year, UK Prime Minister Margaret Thatcher implemented policy changes that allowed universities to more easily exploit IP resulting from publicly funded research, analogous to the U.S. Bayh-Dole Act. In 1988, Southern invented a microarray technology and filed a patent on what he created.

Four changes help explain Southern's shift from not patenting the Southern Blot to patenting microarray technologies: UK policy affecting IP; attitudes about patenting among scientists, industry, and government; Southern's role in science; and the increasing complexity and need for development investment in the technologies. The cause-effect relationship between these is complicated and nonlinear, but it is clear that the components changed in parallel between 1973 and 1988. Not patenting the Southern blot in 1973 was not a conscious policy decision, but patenting microarray technologies in the 1980s followed from the increased involvement of private firms in molecular biology, growing acceptance of intellectual property as a result of academic research, increased attention to commercializing such intellectual property to produce social benefits, and increased sophistication about intellectual property among scientists. Edwin Southern's career spans this period of change, exemplified by two seminal technologies that he contributed: the Southern Blot and microarray technologies. 


\section{Acknowledgements}

The authors would like to thank Edwin Southern, Colin Crossman, Suzanna Wood, Donald Mair, Tim Cook, Tom Hockaday, Sherryl Broverman, Tim Lenoir, Joseph Nevins, and Margaret Brill for their valuable time and comments. Also, thanks to the entire research team at the Institute for Genome Sciences \& Policy's Center for Genome Ethics, Law \& Policy at Duke University. This work was supported by a Howard Hughes Medical Institute undergraduate research grant, and the Center for Public Genomics, funded by the Department of Energy and National Human Genome Research Institute through grant P50-HG003391.

\footnotetext{
${ }^{1}$ Corresponding author: bob.cd@duke.edu

2 Tom Roderick, a mouse geneticist, first coined the term "genomics" in 1986 to describe studying
} DNA as whole chromosomes, entire genomes, or large clusters of genes. B. Kuska. Beer, Bethesda and biology: How "genomics" came into being. Journal of the National Cancer Institute 1998; 90 (Jan 21): 93. "Genome" is an older word, created in 1920 by Hans Winkler, Professor of Botany at the University of Hamburg. H. Winkler. 1920. Verbreitung und Ursache der Parthenogenesis im Pflanzenund Tierreiche. Jena. Gustav Fischer Verlag.

${ }^{3}$ E.M. Southern. Telephone interview. June 22, 2005.

${ }^{4}$ Ibid.

${ }^{5}$ Though Walker was a professor of Zoology, he was also a brilliant engineer. As part of his Ph.D. thesis work in the 1950s, for example, he developed a high resolution, ultra-violet microscope that could scan cells to measure nuclear DNA content. Walker also created an analytical centrifuge and other optical devices, and is the author of the definitive Chambers Dictionary of Science and Technology, now in print for well over 50 years.

${ }^{6}$ Southern, op. cit. 3 .

${ }^{7}$ E.M. Southern. Blotting at 25. Trends in Biochemical Sciences 2000; 25(12): 585-588.

${ }^{8}$ Ibid.

${ }^{9}$ T.J. Kelley, Jr. and H.O. Smith. A restriction enzyme from Hemophilus influenzae: II. Base sequence of the recognition site. Journal of Molecular Biology 1970; 51(2): 393-409.

${ }^{10} \mathrm{~K}$. Danna and D. Nathans. Specific cleavage of simian virus 40 DNA by restriction endonuclease of Hemophilus influenzae. Reviews in Medical Virology 1971; 9(2): 75-81.

${ }^{11}$ Southern, op. cit. 7.

${ }^{12} \mathrm{~F}$. Sanger et al. A two-dimensional fractionation procedure for radioactive nucleotides. Journal of Molecular Biology 1965; 13(2): 373-398.

${ }^{13}$ For a detailed discussion of the Southern blot methods, see Southern's 1975 publication. E.M. Southern. Detection of specific sequences among DNA fragments separated by gel electrophoresis. Journal of Molecular Biology 1975; 68(3): 503-517.

${ }^{14}$ Southern's 1975 paper describing the Southern blot is currently the most cited paper in the Journal of Molecular Biology, cited 31,032 times as of 27 October 2005. (This citation figure was found through a citation search of Southern's 1975 paper on the Web of Science.)

${ }^{15}$ Southern, op. cit. 7.

${ }^{16}$ Southern, op. cit. 3.

${ }^{17}$ Southern, op. cit. 7.

${ }^{18}$ Southern, op. cit. 3.

${ }^{19}$ Creative Commons. Available from http://creativecommons.org/license/?format=text. Accessed 5 December 2005. Two works help to explain the Creative Commons concept: L. Lessig. 1999. Code and Other Laws of Cyberspace. New York, NY. Basic Books. See also B.M. Hill. 2005. Towards a Standard of Freedom: Creative Commons and the Free Software Movement. Available from http://mako.cc/writing/toward_a_standard_of_freedom.html. Accessed 5 December 2005.

${ }^{20}$ The first Southern patent on record was applied for 29 September 1986, and resulted in European patent 238,602, published 9 September 1992 (corresponding to several other patents in various jurisdictions, based on this same invention.) A search of patents on Delphion patent database 28 October 2005 for European, US, Japanese, German, Patent Cooperation Treaty, and International Patent data sets returned 93 patents for [Inventor: "Southern" AND "Edwin”]. 


\footnotetext{
${ }^{21}$ For more comprehensive information about British government under Attlee, see: Nick Tiratsoo. 1991. The Attlee Years. London, New York: Printer Publishers.

${ }^{22}$ Treasury Circular No. 5/50. United Kingdom Parliament House of Commons; 1952. "National

Research Development Corporation. Report and Statement of Accounts for the year 1st July, 1950, to 30th June, 1951." Transference of Government Rights in Inventions to the National Research Development Corporation. (House of Commons Paper 83) Sessional Papers 1950-1951 vol. 18. London. HMSO: 12.

${ }^{23}$ The NRDC joined with the National Enterprise Board (NEB) to form the British Technology Group (BTG) in 1981. See: BTG History. Available from http://www.btgplc.com/compliant/companyoverview/btgshistory.cfm. Accessed 26 October 2005.

${ }^{24}$ K. Flanagan and M. Keenan. 1998. Trends in UK Science Policy. In Science and Technology in the United Kingdom, $2^{\text {nd }}$ Ed. P. Cunningham, ed. London. Cartermill International: 26.

${ }^{25}$ House of Commons. 1985. Parlimentary Debates, Sixth series, volume 79, House of Commons Official Report, Session 1984-85. London. HMSO: 97-100w.

${ }^{26}$ P.L. 96-517; 35 USC 18.

${ }^{27}$ A.J. Stevens. The Enactment of Bayh-Dole. Journal of Technology Transfer 2004; 29(1): 93-99.

${ }^{28}$ J. Baker. "Creating Knowledge, Creating Wealth" Realising the Economic Potential of Public Sector Research Establishments. Available from http://www.hmtreasury.gov.uk/Documents/Enterprise_and_Productivity/Research_and_Enterprise/ent_sme_baker.cfm Accessed 22 November 2005.

${ }^{29}$ Office of Science and Technology. HM Treasury. The Government's Response to the Baker Report: "Creating Knowledge, Creating Wealth" Realising the Economic Potential of Public Sector Research Establishments. Available from http://www.hm-treasury.gov.uk/media/23D/D3/57.pdf. Accessed 22 November 2005.

${ }^{30}$ For more information on the history and work of Isis Innovation, see Isis Innovation Official Website. Available from http://www.isis-innovation.com/. Accessed 08 July 2005.

${ }^{31}$ Southern, op. cit. 3.

${ }^{32}$ Ibid.

${ }^{33}$ Ibid.

${ }^{34}$ Some claims of these patents were later judged overly broad during appeal to the House of Lords in the United Kingdom. Biogen v Medeva [1997] RPC 1 HL.

${ }^{35}$ Southern, op. cit. 3.

${ }^{36}$ Ibid.

${ }^{37}$ Press Release. Oxford Gene Technology. Oxford Gene Technology Steps Up Attack on Affymetrix Patent Litigation. 15 December 1999.

${ }^{38}$ Southern, op. cit. 3.

${ }^{39}$ Ibid.

${ }^{40}$ Ibid.

${ }^{41}$ J. Walsh et al. 20 September 2005. Patents, Material Transfers and Access to Research Inputs in Biomedical Research. Final Report to the National Academy of Sciences' Committee Intellectual Property Rights in Genomic and Protein-Related Inventions, p. 5.
} 